Portland State University

PDXScholar

6-2-1998

\title{
Opus Caementicium: My Work in Concrete
}

Thomas J. Botkin

Portland State University

Follow this and additional works at: https://pdxscholar.library.pdx.edu/open_access_etds

Part of the Sculpture Commons

Let us know how access to this document benefits you.

\section{Recommended Citation}

Botkin, Thomas J., "Opus Caementicium: My Work in Concrete" (1998). Dissertations and Theses. Paper 5823.

https://doi.org/10.15760/etd.7694

This Thesis is brought to you for free and open access. It has been accepted for inclusion in Dissertations and Theses by an authorized administrator of PDXScholar. Please contact us if we can make this document more accessible: pdxscholar@pdx.edu. 


\section{THESIS APPROVAL}

The abstract and thesis of Thomas J. Botkin for the Master of Fine Arts in Art:

Sculpture were presented June 2, 1998, and accepted by the thesis committee and the department.

COMMITTEE APPROVALS:
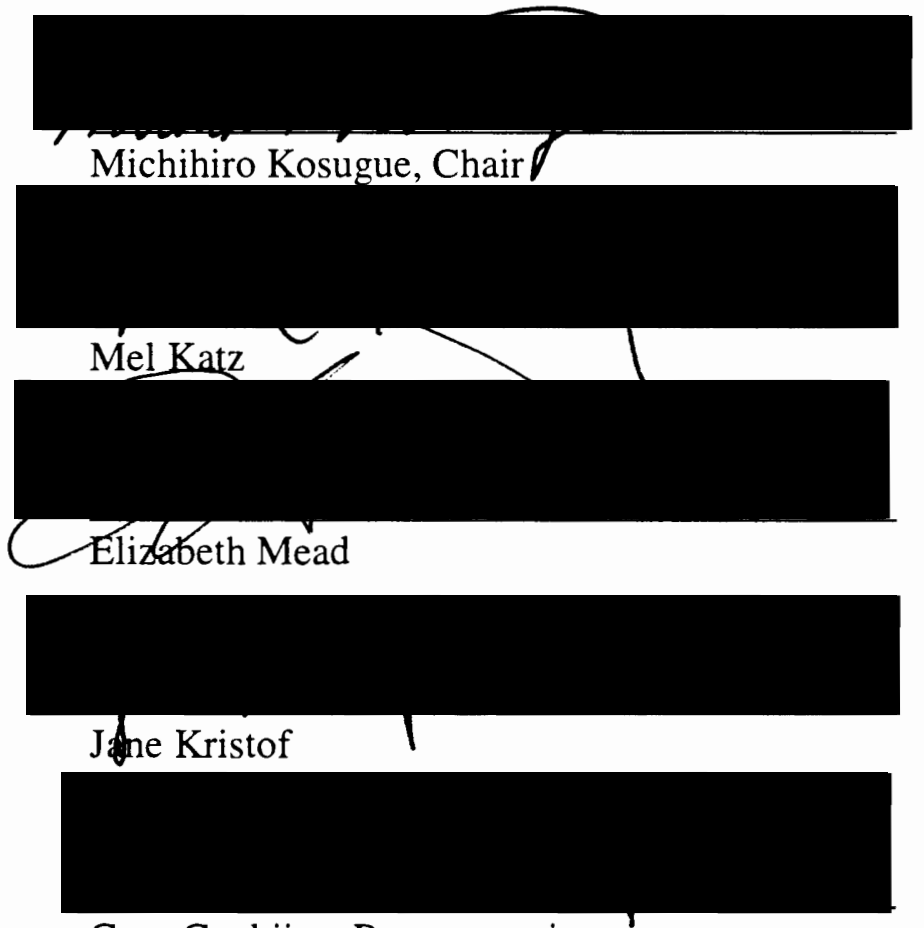

Greg Goekjian, Representative

Office of Graduate Studies

DEPARTMENT APPROVAL:

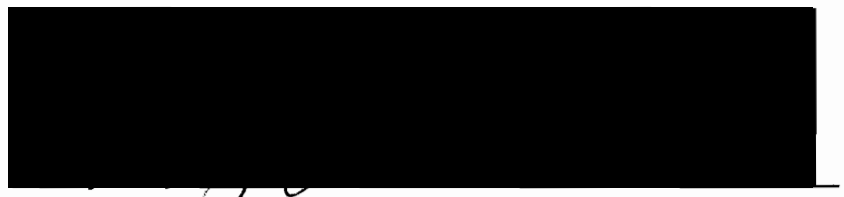

Mary Constans, Chair

Department of Art 


\begin{abstract}
An abstract of the thesis of Thomas J. Botkin for the Master of Fine Arts in Art: Sculpture presented June 2, 1998.

Title: Opus Caementicium: My Work in Concrete.

I developed an interest in concrete by working in the building trades. How could such a base material be so fascinating? It had the fluidity of a lava flow, the ugliness of scat and the power of gravity. The last two years have been spent using concrete as a sculptural material. The results of my research "Flips," "Fills," and "Plops," are inquiries into the nature of concrete.
\end{abstract}


OPUS CAEMENTICIUM:

MY WORK IN CONCRETE

\author{
by \\ THOMAS J. BOTKIN
}

A thesis submitted in partial fulfillment of the

requirements for the degree of

MASTER OF FINE ARTS

in

ART: SCULPTURE

Portland State University

1998 


\section{DEDICATION}

This work is dedicated to James Vernon Botkin, Gwendolyn Reid Botkin, and Un Sok Choi for their parental love and care. 


\section{ACKNOWLEDGMENTS}

I have many to thank for their help in this process: first of all, thank you to my wife, Nora Kirschner, for her unwavering support and love, Maya, our child an inspiration for all, and to her grandmother, Margit Lee, for taking on the daily responsibilities of early child care. I thank Michihiro Kosugue for his encouragement to enter the MFA program, and for his continued research advice. If not for this I would not be receiving this degree. Thanks to Mel Katz, Elizabeth Mead and Eleanor Erskine for their consistent positive studio visits and observations. Thank you to my thesis committee, Mel Katz, Elizabeth Mead, Jane Kristof, and Greg Goekjian, for their willingness to participate in not only this specific part of the process but for their genuine care in seeing it all to fruition. . A deeply felt thank-you goes to Sue Taylor for her patient editing and advice. And finally, to all the faculty in the PSU art department with whom I have worked in pursuing this research. 
TABLE OF CONTENTS

PAGE

LIST OF FIGURES

iv

INTRODUCTION

1

THESIS AND ITS DEVELOPMENT

4

CONCLUSION

16

FIGURES

17

BIBLIOGRAPHY

25 


\section{LIST OF FIGURES}

FIGURE

\section{PAGE}

1. Lynda Benglis, Adhesive Products, 1971

2. Thomas Botkin, Red Flip \#1, $1997 \quad 18$

3. Rachel Whiteread, House, $1993 \quad 19$

4. Robert Smithson, Concrete Pour, $1969 \quad 20$

5. Thomas Botkin, Two Bag Plop \#40, 1998

6. Thomas Botkin, Installation of Plops, 1998

7. John Chamberlain,

Small Monument to a Swiss Monument, 1979-82 23

8. Thomas Botkin,

Two Bag Plop \#40 with group, 1998 


\section{OPUS CAEMENTICIUM: My Work in Concrete}

\section{INTRODUCTION}

This research began with an interest in examining the "other side." That is, seeing what is not usually seen because the front or top view is in the way. To develop this idea I started with fiberglass screening and silicon or latex caulk. Using a wide-bladed putty knife I pushed the caulk through the screen and then turned it over. With clear silicon based caulk the results looked as if it were the skin or fur of a fantastic creature which was made up of thousands of miniature glass beads. If I used white caulk, the creature had weird yellowing white fur. As a sculptor, I didn't develop a dialog with the material qualities of these skins. So I turned to concrete. It was the mass of concrete that led to an interest in the void. Because the qualities of this material seemed at first to need containment, and containment meant building or finding a void, I built molds, constructed voids. In turn the constructions gave way to casting natural voids found in the landscape and setting up loose definitions of the void around us. These approaches still involve aspects of the other side and so are the same as the approach with the screens.

Concrete has always interested me. When I built houses I usually noticed the mixing truck as it pulled up and poured the liquid into the foundation or driveway forms. I found myself watching the concrete slide down the long sluice, stressing the forms as 
they were filled. Sometimes the forms would ooze concrete or break under the enormous pressure. The oozing and the manner in which concrete moved was fascinating. Now as a sculptural material it references my life and experience. I'm accustomed to and enjoy physical labor which has transferred to my work as an artist. It follows that there would be a conscious desire for a physical dialog with sculpture I create. Concrete has allowed this through its mass and the way I control it. Concrete is common, available and castable. It has a long tradition of use within Western civilization but I felt that its creative possibilities could be studied further.

Combining the elemental ingredients of fire, air, earth, and water, concrete forms a material that looks like it naturally occurred in spite of its technological origins. The fire and oxygen in a kiln dries the lime which forms the cement. When combined with the sand, aggregate and water form concrete. The naturalness of it is very important to me as I have a great interest in nature and the natural. Concrete allows me to explore the issues of control and chance, specifically in relation to its inherent fluidity. Finally, I chose concrete because it is challenging. It can be made to be beautiful but there is an absence of that inherent expectation of beauty found in other more traditional sculptural mediums. Bronze and marble, for example, are beautiful just as material a little patina or polish and they catch and reflect light, immediately attracting one's eye. With concrete there is not that immediate expectation. Commonly it has been known as a building or construction material ever since the Romans invented it in 
the second century $\mathrm{BC},{ }^{1}$ and to date it is still found under our feet and as part of or under our buildings. It is a building block, or foundation and this familiarity makes it easy to overlook. I have categorized the results of my research as "Flips," "Fills," and "Plops," studies into the nature of concrete. Within each category the orientation of the sculpture shifts. The flips are primarily concerned with the discovery of the "other side" and are oriented by leaning against the wall with the molded surface exposed.

The fills have the combined qualities of the other side and verticality while referring to gravity. The plops also refer to gravity's effects, and additionally are organic descriptions of space. All of these however are various expressions of the void. This work elevates concrete to the aesthetic, and therefore sheds a new light on it. 


\section{THESIS AND ITS DEVELOPMENT}

\section{Control or Chance}

The balance of control and serendipitous outcome is one of the forces behind my sculpture. When I talked with Professor Michi Kosuge about the issue he said I was trying to control the material too much and suggested finding that balance between controlling and not controlling the material, using the hand to control the work but having no blatant evidence of it. I interpreted this as not allowing the work to look manipulated. ${ }^{2}$ One artist whose work my sculpture has an affinity with is Lynda Benglis. In her relationship with the material she realized early that "matter could and would take, finally, its own form."3 With Adhesive Products 1971, Benglis built armatures coming off the wall, and over them poured polyurethane material, allowing the natural properties of the material to dictate how it covered the armature. In this way her work does not relate to the issue of the "other side" but it does relate to the plops. Benglis' sculpture is controlled but the work does not look controlled (fig. 1). Just as Benglis discovered the physical properties of polyurethane, I have learned about concrete's particular characteristics. Control verses chance, the balance is determined by developing a dialog with the material. The control is evident but the sculpture also appears to be a natural phenomenon.

${ }^{2}$ Conversations and observations based on regular frequent visits to Professor Michihiro Kosuge's studio, 1996-present.

${ }^{3}$ Susan Krane, Lynda Benglis: Dual Natures (Atlanta: High Museum of Art, 1991), 23. Specifically, it is Benglis's polyurethane works like Adhesive Products, 1971, and others made in the same year with which my work has affinities. 
Flips

First came the "flips," a two-dimensionally oriented body of work. I built flat rectilinear molds into which I poured concrete, looking for interesting results once the mold was stripped away. I found some of this mold material in the hallway outside my studio. It usually consisted of discarded paintings or collages around which I built a fence to create the mold. The molds at times contained various loose elements including paint, wood, cloth, wax, plastic bags, styrofoam and other material. After the concrete was set, I would strip away the mold and flip the work up against a wall or over onto its back. The first pieces were heavy and looked like chunks of broken sidewalk that were poorly laid. But sidewalks are about the top surface and I was interested in a recording of the mold or void underneath (fig. 2). Initially the work appeared to engage painterly issues, involving flatness, the implied frame, and other aspects of the surface, such as texture, color, and tonality, which were raised by some of the residual elements in the mold. In a sense, these objects were paintings, but the intent was to visualize the void, and whether or not the flips looked like paintings was incidental. These are heavy panels and when leaning against a wall as a group they could make up the facade of a building. But they have many interesting individual characteristics that draws the viewer to them as separate units. 
Fills

I wanted more information than what I was getting with flips. The fills began as vertical, freestanding hollow forms that were made of construction materials, mostly wood. The molds were built as loosely and spontaneously as possible, sometimes including unattached elements of wood or plastic sheeting. This approach gave them their own sculptural integrity. There were many times when the mold was more interesting than the resulting concrete sculpture. With four or five fills demanding their own space in the studio, they definitely had a presence, making a crude gallery of my studio as if a naive construction worker had decided to make sculpture in it. The molds had an odd, rough, poorly constructed appearance and looked heavy despite their relatively light weight. Some of them had figurative elements and others reminded me of sarcophagi. The scale of the molds was typically life-size or just under life-size. They carried on a dialog between themselves. Skinny and tall with unfinished wood surfaces, the molds already were sculpture; however, I poured the concrete into them anyway. Many of the molds would bulge under the weight of the concrete, and sometimes concrete would ooze from, or even break the mold. The mold then would have to be destroyed or stripped away to uncover the sculpture. Some of them became figurative, caryatid-like, having folds that appeared to be skin or fabric created by the loose plastic sheeting and the bulging forms. The fills carried much of the same information as the flips, only rather than my turning or flipping the piece over, I merely pulled the mold off, stripping it from the concrete. The fills were 
related to the work of Rachel Whiteread and are a good example of my interest in the void. In House, 1993, she filled the entire interior of a London row house with concrete (fig. 3). Using a variety of cast materials, Whiteread initially cast voids of rooms, closets, and the spaces beneath chairs. ${ }^{4}$ My sculpture is not related to the domestic and architectural issues Whiteread addresses, and in the case of the fills, are not a description of found objects. I built my molds. Her approach has led me to an increased interest in unknown, unseen, and unfilled voids. This is the connection between her work and mine. Defining the void, whether an interior space or a naturally occurring space is the goal.

\section{Discovery}

With these flips and fills an unexpected issue arose, that of surprise or discovery. I looked forward to stripping the mold away and/or flipping the sculpture over. What would it look like when the concrete hardened and the mold was stripped away? Initially the void was the main interest, but soon I realized that the act of uncovering or stripping off the mold also was uniquely important. It was much like looking at the other side of the earlier fiberglass screens. There were many times I wondered what it would be like to flip over sections of sidewalks or foundations, wherever concrete was used. Even if this flipping ultimately proved to have interesting results my fascination 
would still have been in the act and fact of exposure. I wished to leave no stone unturned and to expose the unexposed. This is part of my process. Anticipation is powerful, after all, cannot the partially dressed figure be more interesting than the nude? The uncovering at times leads to disappointment and alludes to Kenneth Clark's "Ideal." It is not so much what is uncovered but the fact that it is uncovered. This aspect of discovery only begins to explore human nature and the desire to see what is on the other side or under side. It raises questions regarding the role of desire and the objectification in art and art making.

Plops

I abandoned constructing the mold, and have since produced a number of concrete shapes that describe organic voids or spaces. They appear as and are named, plops of a highly viscous material. Typically I mix two eighty-pound bags of concrete, then with steel or iron reinforcement place the concrete to surround an object, fill a natural void or just cover a surface, depending on my intuition. The surfaces are covered or lined with visquene, a heavy plastic sheeting. As gravity does its work, I control parts of the form by pulling up the edges of the visquene and loosely securing it. The effect is somewhat like that of a cow pie but some areas of the shape mimic pillow-like forms. There are scatological aspects in this work. This occurs because of the effects of gravity on the material and the control I assert. It still is an unanswered question, 
but my focus remains on the nature of the material regardless of its manifestations. Plops resemble a lava flow but one that is cold now, not consuming or destroying but rather a productive force that created organic forms and shapes. Robert Smithson in the 1960s and early 1970s made what he called "pours." In Chicago, Concrete Pour, 1969, was made by dumping the concrete from a large mixer truck down a semiremote slope, which formed an alluvial-like fan (fig. 4). ${ }^{6}$ Smithson's motivation was in part similar to Benglis' but on a much larger scale. The process has been much discussed in terms of commentary on the heroic procedures of Abstract Expressionist painting, but no one has considered what the resulting forms or shapes were, what the pours looked like on both sides, top and bottom. Wouldn't it be interesting if we could flip them over? Like organic, accidental or found forms, they could reveal unseen, naturally occurring forces. My interest has developed into a search for the unstructured, the organic void. It addresses defining the void and the space around us--the space whose initial manifestation in relation to the plops, is the place where the effects of gravity on the fluid concrete meet resistance, such as the ground. This entire process defines gravity literally and despite the final orientation of the plops they will always say, "this way, I was going this way."

${ }^{6}$ Robert Hobbs, Robert Smithson: Sculpture (Ithaca, N.Y.: Cornell University Press, 1981), 170-80. 
Aesthetics

Although concrete's beauty is not readily apparent, some simple techniques give it aesthetic appeal. Visquene or plastic sheeting, when brought in contact with wet concrete, can leave an incredibly smooth surface, mimicking the surface of the plastic. The concrete records the folds and wrinkles while the visquene allows the concrete to swell. This technique gives the sculpture a layer of "otherness." That is, the material becomes something other than what it is. The addition of pigment adds another layer by changing the appearance and visual weight of the sculpture. I mixed commercial pigment with the liquid material and handled the rest of the process as usual. This distanced the material from its commonly known associations. The first impression was not of "concrete" but a clearer reading of the shapes and forms. The material had an altered physical reality when compared to the un-pigmented versions of the sculptures. The effect of combining visquene and pigment in the process on one hand became an easier to read description of the void, but on the other hand denied identification of the material (fig. 5).

Context, Time, and Space

The plops have a sense of natural forces, like a lava flow or a cow pie. They are isolated as individual pieces, but when they are grouped together, the sculptures assume a serenity like that of a Zen rock garden. They are stark and immobile. If the sculptures were not in a gallery they could seem to be a permanent part of a landscape 
produced by volcanic forces. The welling eruptive forms, appear to be expanding and filling space (fig. 6). Pre-historic connotations come to mind when looking at this work, dinosaur bones, black and gray. They are obviously not real but they suggest a metaphorical pre-historic skeleton, or the metaphor of an geological age or period. In this way the sculptures appear archeological or geological. They are witnesses to a process which I and/or the viewer can observe, study and appreciate. This is like a scientific inquiry, but one which the artifacts are created as a product of research.

This research into visualizing voids and surfaces is a responsive, or impulsive reaction rather than premeditated action. Rachel Whiteread's work, on the other hand, takes much thought and planning. In House, for instance, she first sprayed gunite, a form of concrete, over all the surfaces, added reinforcing wire mesh and then added more concrete. In the process she realized the foundation of the house was weak, so work stopped until the structure's foundation could be reinforced. Her work is important to me because it actualizes the void, but the technical requirements seem cumbersome and inhibiting. My technique is intuitive and spontaneous. I quickly record the overlooked areas around each of us and then observe what I make without too many mediating procedures to muddy the act. For me it is spontaneity and immediacy that mark the moment. Sometimes the concrete captures loose objects or debris, trapping and/or embedding them in the surface. At times these objects leave only impressions 
in the concrete, but are enough evidence to record a specific time and place. The facts are, all castable material, and in this case the specific qualities of concrete, refer to the indexical aspects that Rosalind Krauss writes about in her influential essays "Notes on the Index: Parts 1 and 2". As in a photograph, these "recordings" refer not to the perception of being-there but of having-been-there.' My sculpture refers to the swell and hollow of a ditch and its contents, but the sculpture is not the ditch. It is this indexical relationship with the landscape that relates to, but does not derive from Smithson's Site, Non-site works, and illustrates my work. Smithson drew detailed maps and made bins to contain material mined from the original site. The bins had cutout profiles of the site built into them as reference ${ }^{8}$ This indexical quality is a byproduct of my interest in landscape.

\section{Bases and Orientation}

These flips, fills, and plops, the recordings of surfaces, forms and voids, can become entirely new when placed in a new context or oriented in a new position. In a sterile or neutral environment, they become easier to read. Changing the orientation can also assist the viewer in seeing my sculpture. It is most often the outdoor environment that provides the voids, found spaces and inspiration for the sculpture but it does not 
demand a place either indoors or outdoors. Thus the reading of the sculptures can vary with the context.

As my work develops, two major considerations have manifested themselves. The first is the base. Michi Kosuge has suggested considering the base with some of my sculpture. The steps in the process of making plops that are cast on a mound or slope, has lead me to placing supports or bases under some of the sculpture. I have found that a prop placed under this new work is one solution to orienting some of the sculpture. But the props need to be of the same material as the sculpture. So far I have used cut concrete and leftover elements from the plops. The more successful props are the leftovers because they have the same organic feeling and definition as the plops themselves and they are part of my inquiry. One helpful resource is the example of Chinese scholars' rocks. These rocks were collected by and associated with the literati from the tenth century to the present. They became aesthetic inspirations and were placed on stands or pedestals to separate them from ordinary stones. The bases also served to orient the rocks in a way that enhanced their metaphorical content. In many cases, the bases carried their own aesthetic weight complementary to the rocks. ${ }^{9}$

\footnotetext{
`Debra Balken, “China's Stony Icons," Art in America 85 (November 1997): 101-3.
} 


\section{Continued Development}

Another consideration addresses scale. I wanted to work bigger. But to achieve this realistically seemed impossible. Some of the early sculptures were four hundred to five hundred pounds, and they were difficult to move. I began to think back on discussions with Michi Kosuge, who suggested grouping the sculptures together. I thought about this and was disinclined because I thought that meant "installations" and at the moment that wasn't what I wanted to do. Mel Katz proposed stacking the work, and like Michi, talked about grouping the pieces together, but there seemed to be too much disparity in the work to make stacking or grouping look cohesive. Both professors however helped point me to my present way of thinking: I began placing one plop along side of, or on top of, another and so forth in the process of casting them. I first made my usual plop, then once that was cured or set I placed a sheet of visquene over it and placed a second plop on top of the first. When the second one cured, I placed a third plop on top of the first two, following the seam between the two. The scale had suddenly increased in a previously unthought of manner. I can now separate and move the work without much effort, and if I choose, show each plop individually. The effect of the interlocking or interlaid plops is at first like a magnification of the lava-like accumulation, and as I look more closely at the seams between the individual plops they begin to inform one another. The larger, unified sculpture becomes self-referential because it's made up of casts of itself. The self- 
referencing happens as the form of one plop is found in reverse in the plop immediately next to it. The interlocking pieces and the way they so individually fit together relate to John Chamberlain's sculpture (fig. 7). Chamberlain talks of how his work is about the "squeeze" and the "fit." His material is painted automobile sheet metal. He takes any number of metal pieces of various sizes and colors and presses them together in a machine of the type used to compress old car bodies in scrap yards. The finished sculpture is then welded at key points to secure the various units, but they all fit together. ${ }^{10}$ If Chamberlain chose, he could separate a piece from the whole. This piece would have a memory of where it fit. It is this quality of memory to which my work refers, only the process is different (fig. 8).

${ }^{10}$ David Bourdon, "Artists Dialogue: John Chamberlain, the Squeeze and Fit," Architectural Digest 42 (November 1985): 70-81. 


\section{CONCLUSION}

Through Opus Caementicium I have explored the nature of concrete, a material not commonly used for art. With flips, fills and plops I have examined issues relating to control versus serendipity in my work. I have acknowledged the role of desire in my work with the material, the process and its references. The sculpture records the voids, time and space. By removing the sculpture from where it was created I acknowledge the void and must address the questions of presentation, base and orientation. 


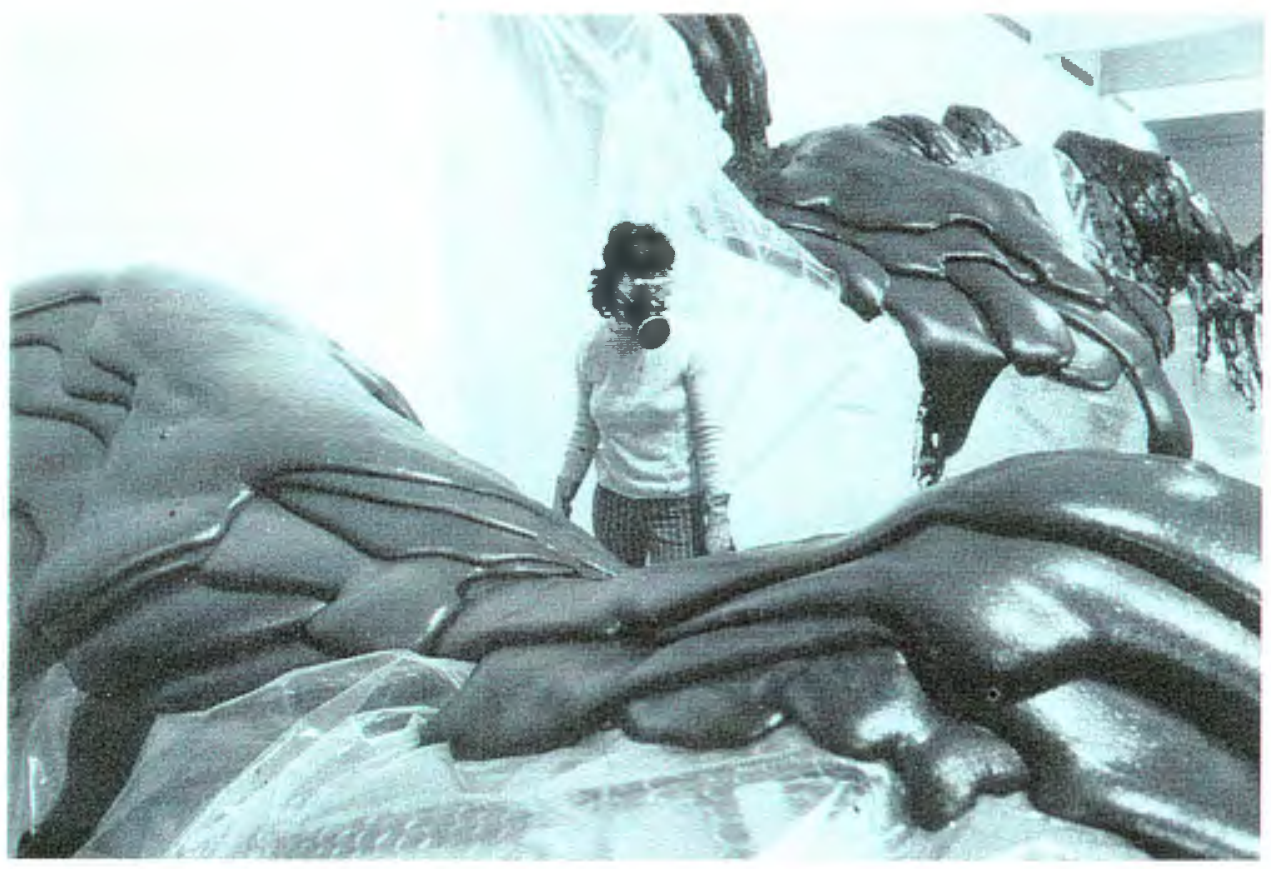

Figure 1 Lynda Benglis, Adhesive Products, 1971 


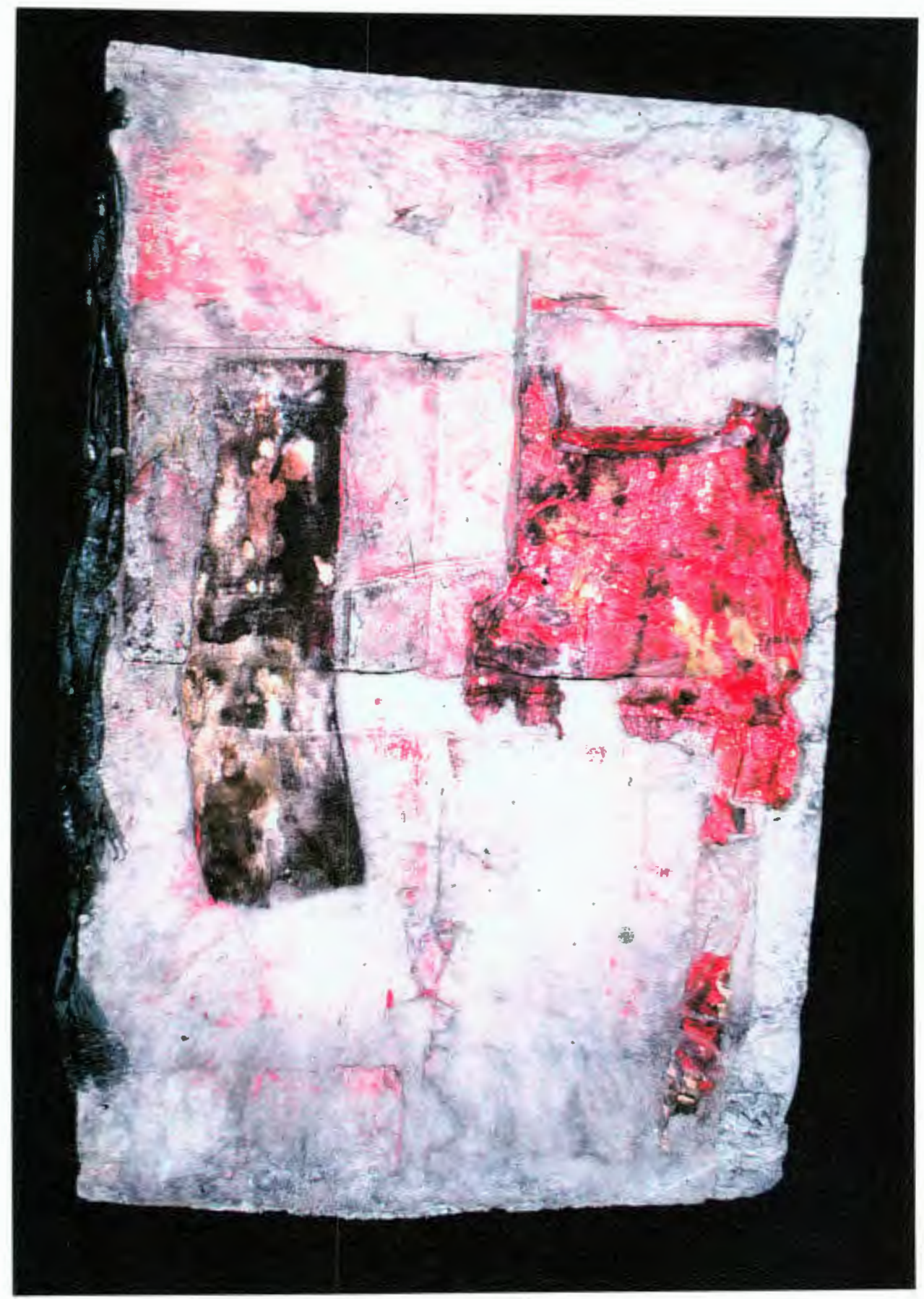

Figure 2 Thomas Botkin, Red Flip \#1, 1997 


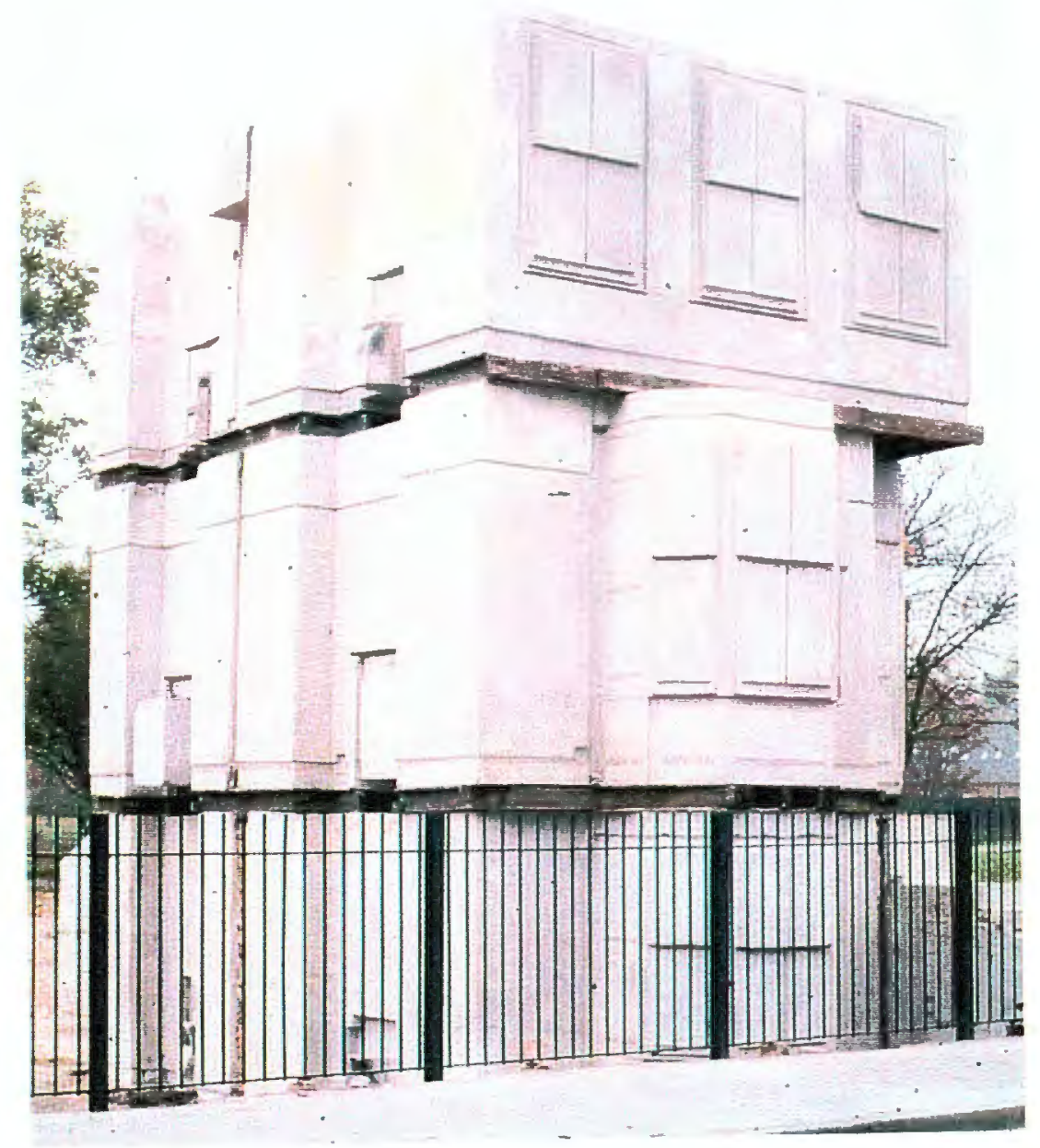

Figure 3 Rachel Whiteread, House, 1993 


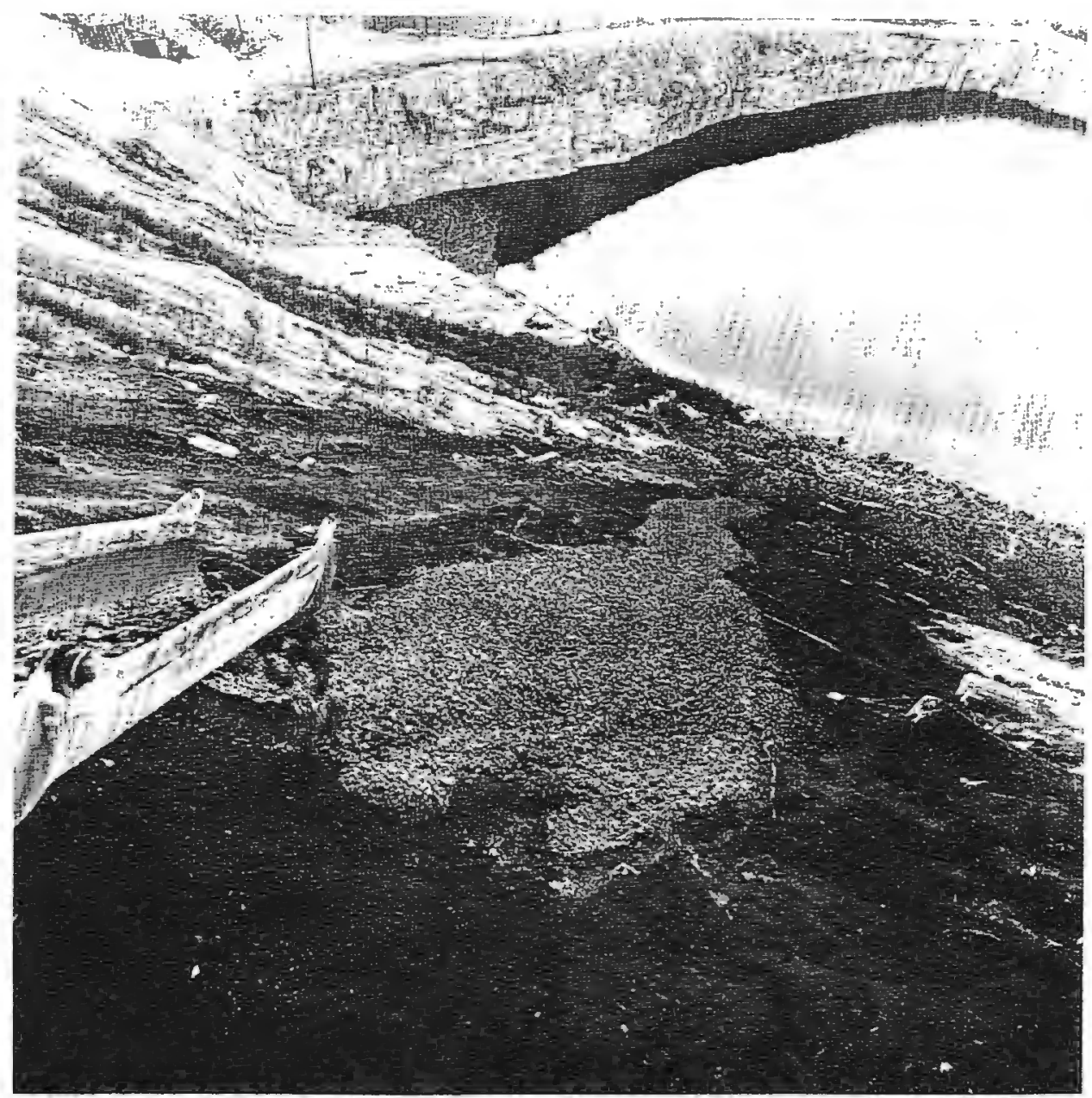

Concrote Pour. Chicago, November 1969. Courtsey Museum of Contemporary Art. Chicago. Photograph courtesy Dwan Gallery, Inc.

Figure 4 Robert Smithson, Concrete Pour, 1969 


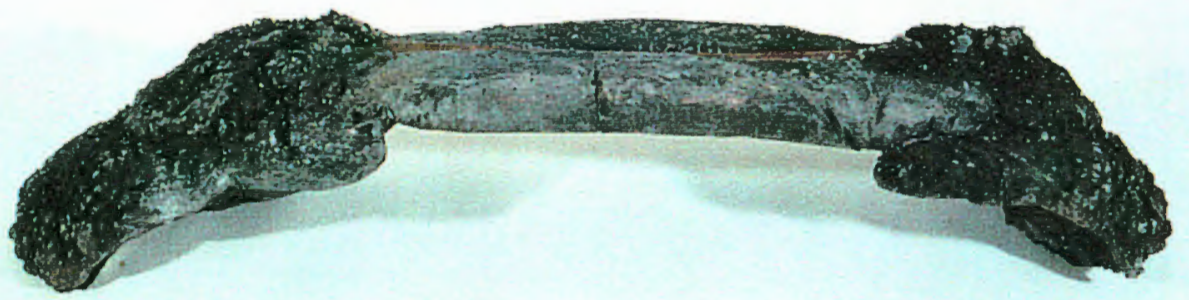

Figure 5 Thomas Botkin, Two Bag Plop \#40, 1998 


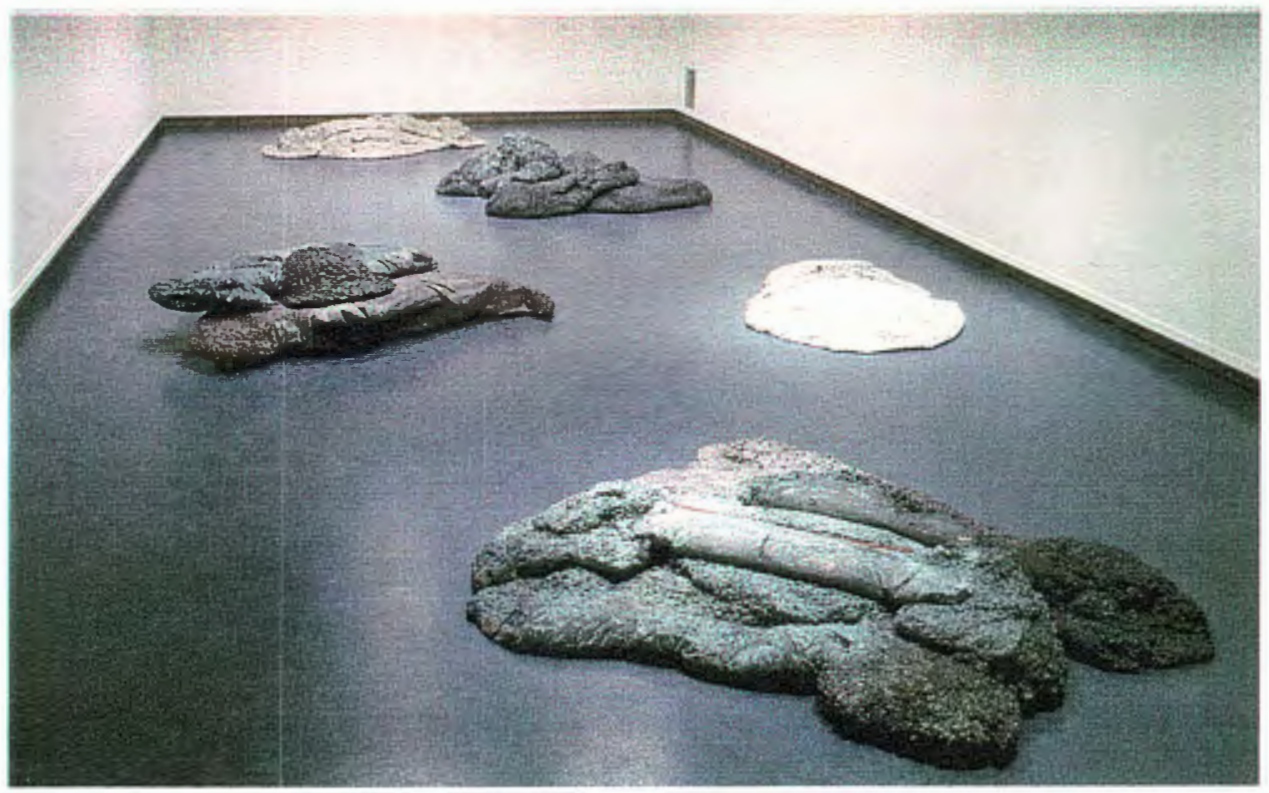

Figure 6 Thomas Botkin, Installation of Plops, 1998 


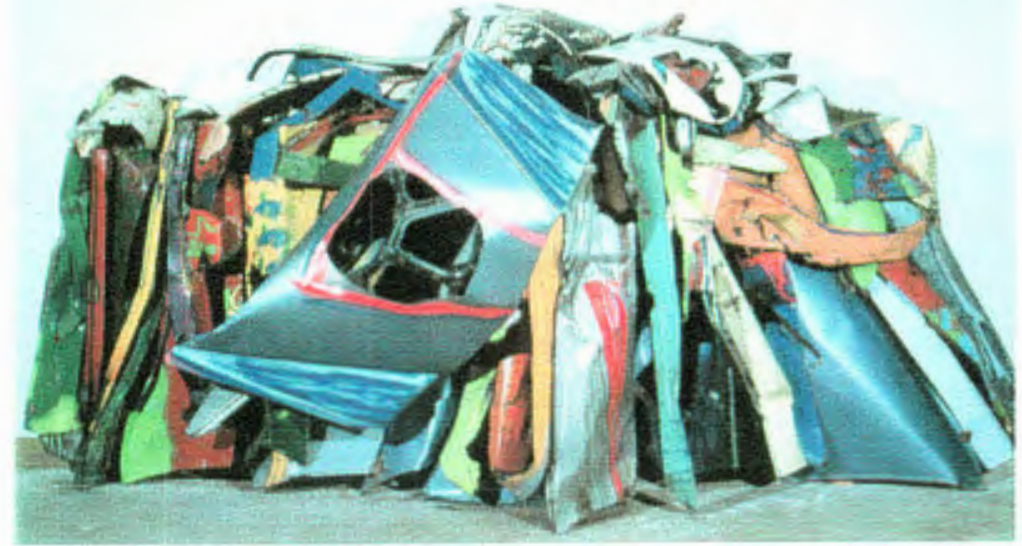

Figure 7 John Chamberlain,

Small Monument to a Swiss Monument, 1979-82 


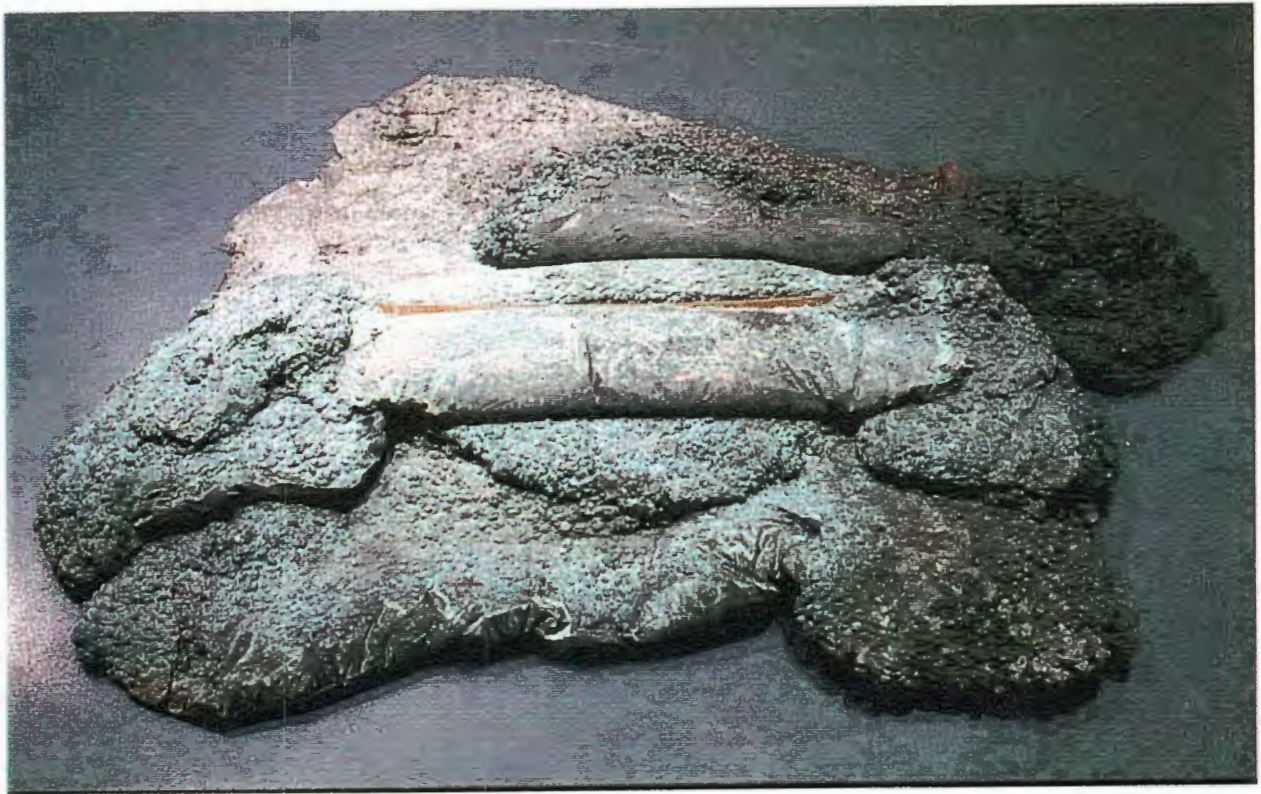

Figure 8 Thomas Botkin, Two Bag Plop \#40 with Group. 1998 


\section{BIBLIOGRAPHY}

Balken, Debra Bricker. "China's Stony Icons." Art in America 85 (November 1997): 100-3.

Bois, Yves Alain and Rosalind Krauss. "A User's Guide to Entropy." October 78 (Fall 1996): 38-88.

Bourdon, David. "Artists Dialogue: John Chamberlain, the Squeeze and the Fit." Architectural Digest 42 (November 1985): 70-81.

Clark, Kenneth. The Nude: A Study In Ideal Form. Princeton: Princeton University Press, 1956.

Hobbs, Robert. Robert Smithson: Sculpture. Ithaca, N.Y.: Cornell University Press, 1981

Krane, Susan. Lynda Benglis: Dual Natures. Atlanta: High Museum of Art, 1991.

Krauss, Rosalind. The Originality of the Avant Garde and Other Modernist Myths. Cambridge, Mass.: MIT Press, 1985.

McKay, Alexander. Vitruvius, Architect and Engineer. Bristol: Bristol Classical Press, 1978.

Lingwood, James, ed. Rachel Whiteread: House. London: Phaidon Press with Artangel, 1995.

Miller, Joseph Hillis. Versions of Pygmalion. Cambridge, Mass.: Harvard University Press, 1990.

Miller, Sanda. Constantin Brancusi, A Survey of His Work. Oxford: Clarendon Press, 1995.

Rubenstein, Raphael. "Abstraction Out of Bounds." Art in America 85 (November 1997): 104-16. 